\title{
Analysis on New Village Settlement Difficulties of Post Disaster Reconstruction Path under New Rural Construction Background ----Taking Sushan Village, Qianjin Town, Mingshan District of Ya'an City as an Example
}

\author{
Zheng Linfeng \\ College of Literature and Law \\ Sichuan Agricultural University \\ Ya’an, Sichuan 625014 China
}

\author{
Wang Shiyou \\ College of Literature and Law \\ Sichuan Agricultural University \\ Ya’an, Sichuan 625014 China
}

\begin{abstract}
On April 20 ${ }^{\text {th }}, 2013$, a magnitude 7.0 earthquake took place in Lushan County, Ya'an City of Sichuan Province, and the earthquake caused the death of 196 people, 21 missing, damaged rural resident housing of 348,600 households, with newly built 150300 households and maintenance and reinforcement of 198300 households. In the great attention of Party Central Committee and the State Council and strong leadership of provincial council and provincial government, the earthquake relief work quickly moves to the post-disaster reconstruction stage. How to promote new rural new appearance construction in disaster region in new rural construction background is related with the life and production of each person. Thus, the districts and counties positively explore reconstruction path, and strive for new rural settlement construction road, and the mountain area is no exception. On June $29^{\text {th }}, 2013$, group 2, Xin'an Village of Xindian Town of Mingshan District held the opening ceremony of the first post-disaster new rural settlement construction of Mingshan District, and the new village point covers an area of about 10 acres, planning to absorb the affected 30 households. There are many towns of new rural settlement planning like Xindian Town. But in actual construction, few villages can smoothly open like Xing'an Village of Xindian Town. Thus, the author visited the relevant towns of Qianjin Town of Mingshan District, Cheling Town, Jiefang Town and Yongxing Town, especially went to Qianjin Town for field investigation. We mainly explore the reasons of new settlement which can not effectively implement and put forward the corresponding suggestions.
\end{abstract}

Keywords: post-disaster reconstruction; new rural construction; rural community; new rural settlement; dilemma;

\section{THE BASIC SITUATION AND DISASTER SITUATION OF SUSHAN VILLAGE,QIANJIN TOWN OF MINGSHAN DISTRICT}

Mingshan District is the original Mingshan County of Ya'an City, located in the southwest edge of Chengdu Plain.
The area is $614.27 \mathrm{sq} \mathrm{km}$, with population of 258500 people, jurisdiction over 9 towns and 11 towns, and on November $6^{\text {th }} 2012$, it was approved by the State Council and Sichuan Provincial People's Govern ment approved a county district. Qianjin Town is located in the southeast of Mingshan District, with Danleng to the east and Hongya to the west, 15 kilometers away from the urban area, 15 kilometers away from State Road 318 line and Chengya Expressway, 90 kilometers away from Chengdu Shuangliu Airport.

Sushan Village is close to the market of Qianjin Town, and the villagers normally market within 15-20 minutes. Now, the population is 508 people, with a total of 113 households and under the juris diction of 4 villager groups, which belongs to a smaller admin istration village in Qianjin Town.

In this earthquake, Mingshan District belongs to heavy disaster area. Sushan Village of Qianjin Town is in this earthquake, and the rural households are destroyed in different degrees. Under the leadership of district government, Qianjin Town government first makes the statistics of disaster situation after earthquake and timely distributes relief materials to victims, with 44 households for reconstruction.

\section{NEW RURAL COMMUNITY AND NEW RURAL SETTLEMENT}

In order to increase the scientific argument, it is necessary to distinguish between the rural community and new rural settlement of the two basic concepts.

New rural settlement and new rural community are two different concepts, and the former focuses on centralized community, but the latter focuses on community. According to the regulations of Chengdu City rural new community construction technical guidelines, the settlement and community are different, the document are clearly classified into different types. 
Table 1: Chengdu City rural new community classification table

\begin{tabular}{|l|l|l|}
\hline Classification & Pooncentration scal & Poushalation \\
\hline Community & $300-2000$ & $1000-6000$ \\
\hline Settlement(goup) & $50-150$ & $200-500$ \\
\hline
\end{tabular}

In 2005, Shandong Province's "Shandong Province rural new community construction technical guidelines" document will also define community scale as the point type of 2400 people.

Table 2: 2005 Shandong Province rural new community rating scale control table

\begin{tabular}{|c|c|c|c|c|}
\hline \multirow{2}{*}{ Area } & \multicolumn{2}{|c|}{ Plain area } & \multicolumn{2}{c|}{ Hilly, mountainous district } \\
\cline { 2 - 5 } & $\begin{array}{c}\text { Household } \\
\text { (household) }\end{array}$ & $\begin{array}{c}\text { Population } \\
\text { (person) }\end{array}$ & $\begin{array}{c}\text { Household } \\
\text { (household) }\end{array}$ & $\begin{array}{c}\text { Population } \\
\text { (person) }\end{array}$ \\
\hline I & $\geq 1500$ & $\geq 6000$ & $\geq 1000$ & $\geq 4500$ \\
\hline II & $\geq 1200$ & $\geq 5000$ & $\geq 800$ & $\geq 3200$ \\
\hline III & $\geq 1000$ & $\geq 4000$ & $\geq 600$ & $\geq 2400$ \\
\hline
\end{tabular}

Note: I area includes Qingdao, Jinan, Yantai, Rizhao, Weihai; II area includes Jining, Zaozhuang, Linyi, Tai'an, Dezhou, Binzhou, Dongying, Weifang, Zibo, Laiwu; III area includes Liaocheng, Heze. 2. The average household is calculated according to 4 persons.

From the provisions of relevant documents, we can see that the difference of community and settlement is reflected in two dimensions: households and population. The deep difference of community and settlement is reflected in: public service and organization structure aspect. Thus, rural community and new rural settlement are two different concepts.

Let's see the definition of academic circle for rural community and new village settlement.

First, community refers to "in a certain natural geographical region, people exchange to naturally form the common regional concept, shared cultural tradition, social customs and life customs and community."[1]

Lou Chengwu's book "community management" expresses rural community as agricultural production as the important living standards population, population density and smaller scale of community [2]. Yu Xianyang thinks that rural community takes rural farming as the main production function or life style, taking villages as the living method, and the village scale is normally very small[3]. Zheng Hangsheng thinks that Chinese characteristics community are under the leadership of party and government, with internal interaction and cultural maintenance and emotional identification regional life community. No matter city community construction and rural community construction, we should strengthen community service[4]. Li Xuebin also thinks that rural community is a function and emotional community [5].

In Zhang Yingju's view, rural concentrated residential refers to that, under the concept guidance of land use planning and science building, in full respect for the wishes of farmers, the replaced households withdraw from orig inal rural residential land, the government takes the part of the reclamation of arable land into the land for construction, and the construction of farmer households in different places around the replacement to the center village or town concentrated residential areas, the traditional and dispersed and scattered settlement are concentrated to the center village and town, in order to achieve land use or land user replacement process [6].

Zheng Fengtian and $\mathrm{Fu}$ Jinhua think that rural concentrated residential is to make farmers in natural villages into residential areas for living. [7]

Zhao Hongbin and Song Fuzhong point out that relatively concentrated living and traditional absolute concentrated and scattered are different. It refers to that according to rural natural geography and economic development environment, it integrates rural advantage resource, to guide preferential policies, taking land transfer as the basic starting point, taking changing rural production and life style as the main content, suiting the local conditions to guide farmers to timely and moderately concentrated living phenomenon.[8]

$\mathrm{Su}$ Yang et al think that rural habitat in China normally refers to the rural population concentrated living place above natural village and county scale, and the greater scale is close to primary towns [9].

From the academic definition, rural community and rural settlement are equal relationship, sometimes it is a relation of inclusion. Thus, we will adopt relevant government's definition, to distinguish from population and scale.

\section{THE IMPLEMENTATION SITUATION OF NEW VILLAGE SETTLEMENT SCHEME IN SUSHAN VILLAGE}

On the third day of the earthquake, Mingshan District government organizes the relevant experts to test the rural damaged houses for evaluation from door to door, in itially determining the repair and reinforcement of the farmers, with town cadres and village cadres accompanied.

Finally it defines that Sushan Village needs to rebuild rural house for 44 houses.

Then, Sushan Village takes groups to have many villager meetings, to tell villagers about relevant policies documents.

After mobilization of the first meeting, it then came the second meeting, then the meeting conducted explanation for the homestead.

But over the next few days, the village cadres were actually worried, some farmers request the withdrawal of settlement, and apply for refund of deposit. Up to now, the whole village are willing to build households, which are only 12 households, 1 group 4 households, 2 group 6 households 3 groups 0 household, 4 group 2 households. Thus, settlement with vigour and vitality abruptly stops, and people have to think about it.

\section{REASON ANALYSIS OF NEW VILLAGE SETTLEMENT OF NOT ACCEPTING BY VILLAGERS}

The author uses the investigation to summarize the villagers not to agree to the construction cause village settlement, mainly in the following aspects: 
First, new village settlement planning area farmers do not accept the land condition.

Second, the affected villagers do not agree with the post disaster housing construction mode. The post disaster reconstruction, the government initial scheme is that the government is responsible for coordinating the homestead and providing apartment layout drawings, then the farmers build housing units according to government drawings for construction. Because in recent years, the rising price of materials, especially the human price rise, many farmers said housing repair is time-consuming activity.

Third, considering the children will not return to the rural areas, many farmers express not willing to build a big house. With the acceleration of city process, rural population constantly moves toward cities, and Sushan Village is no exception.

Fourth, new village settlement planting cost is higher, and the farming is not convenient.

Fifth, they are reluctant to the original wide homestead. According to the survey of the author, Sushan village base covers an area of more than 100 square meters. If coupled with the backyard, some even surpass 200 square meters. Because of getting used to this wide and scattered way of life, many farmers think moving into the house of 90 square meters or 200 square meters are very incommensurate.

Sixth, moving into the settlement will increase living cost, but the income is not correspondingly increased, which may become poor because of settlement.

\section{NEW PATH OF SUSHAN VILLAGE OF QIANJIN TOWN POST-DISASTER RECONSTRUCTION}

First, with full respect for public opinion, when the time is mature, they will not mandatory promote new rural settlement construction.

Second, for the people of not agreeing to move, based on original construction, it encourages local traffic convenient location for construction and living. The retail living is one of the important features of rural living construction, which has higher requirement for rural public service and public equipment. Retail living is one of the important features of rural living construction, which has higher requirement for rural public service and public equipment.

Third, vigorously developing rural economy and improving rural income and laying a solid foundation for integrating rural resources.

Economy is one of the most core factor of restricting Sushan villagers not willing to live together. Hilly areas are not conducive to machine farming, and soil structure is not conducive to the growth of tea. Therefore, even if the villagers live together, a lot of saved land will not be made full use of. So government should help improve the land benefit of hilly areas, to help village community enterprise or develop feature industry.

Fourth, introducing advanced experience, and adopting photos or video form to explain new rural settlement life style and supporting facilities to farmers, letting them have a intuitive and clear recognition for farmers.

\section{CONCLUSION}

In the west countryside of economy relatively backward, constructing new community or settlement is a process, and the government should fully respect the farmers' willingness, do the policy promotion work, greatly develop rural economy, liberating the farmers from the dependence on land, promoting farmers willing to construct new rural settlement or new rural community.

\section{REFERENCES}

[1] Pang Shuqi. Chinese encyclopedia. Social Science volume, [M]Beijing: China Encyclopedia Press, 1991.

[2] Lou Chengwu, Sun Ping. Community management[M]. Beijing: Higher Education Press, 2003:2.

[3] Yu Xianyang. Community overview[M]. Beijing: Chinese Renming University Press, 2006:38.

[4] Zheng Hangsheng. Analysis on Chinese characteristics community construction and social construction - a social science.[J]Journal of South-Central University for Nationalities. 2008(6).

[5] Li Xuebin: Comparison between rural and urban community[J]. Chinese Civil Policy. 2008(5).

[6] Zhang Yingju. Calm reflection of rural concentrated living construction hot[J]Jiangsu Agricultural Science, 2011: 537-540.

[7] Zheng Fengtian, Fu Jinhua. Rural concentrated living status, problems and countermeasures. [J]Rural Research. 2008.06

[8] Zhao Hongbin, Song Fuzhong. Domestic and foreign farmers' concentrated living guidance experience[J]World Agriculture. 2012.12

[9] Su Yang, Cheng Hongguang, Ma Zhouzhou. Study on rural settlement environment problems and " $11^{\text {th }}$ five year plan" period countermeasures[J]City Development Research. 2006.06 